Article

\title{
Does Changing Electoral Systems Affect (Corrupt) Particularistic Exchanges? Evidence from the Italian Case
}

\author{
Simona Piattoni ${ }^{1, *}$ and Matteo Fabio Nels Giglioli ${ }^{2}$ \\ ${ }^{1}$ Department of Sociology and Social Research, University of Trento, 38122 Trento, Italy; E-Mail: simona.piattoni@unitn.it \\ 2 Department of Political and Social Sciences, University of Bologna, 40125 Bologna, Italy; E-Mail: matteo.giglioli@unibo.it \\ * Corresponding author
}

Submitted: 14 February 2020 | Accepted: 7 April 2020 | Published: 28 May 2020

\begin{abstract}
The literature on forms of particularism explores the impact of institutional variables on what is denoted, alternatively, as constituency service, pork-barrel politics, or corruption. Attention has mostly been given to electoral systems, but other institutional provisions and political factors, such as party strength, are also relevant. The present contribution investigates the likely effects of electoral reforms on corruption control and seeks confirmation of the hypothesis that single member plurality (even within mixed member) systems are conducive to a type of particularism that might help fight corruption, taking Italy as a case. We test the impact of two electoral reforms and three electoral systems enacted in Italy between 1996 and 2016, whose primary aim was bolstering enfeebled party leaderships and facilitating the formation of durable governments, and we compare the effort at corruption control of the Italian governments born under these different electoral systems with those of other European democracies.
\end{abstract}

\section{Keywords}

corruption; electoral reforms; Italy; particularism; personalism

\section{Issue}

This article is part of the issue "Fighting Corruption in the Developed World: Dimensions, Patterns, Remedies" edited by Fabrizio Di Mascio (University of Turin, Italy) and Simona Piattoni (University of Trento, Italy).

(C) 2020 by the authors; licensee Cogitatio (Lisbon, Portugal). This article is licensed under a Creative Commons Attribution 4.0 International License (CC BY).

\section{Introduction}

Italy is often singled out as a country characterized by widespread clientelism, bribery, nepotism, and the many other terms that are conventionally used to denote exchanges involving inappropriate public-private transactions and entailing negative consequences for democratic life, economic performance and civil coexistencecorrupt exchanges in the broadest sense. Not all such exchanges are equally dangerous for a country's economy and democracy, yet all have some spillover effects that may lead to graver forms of corruption. It is therefore important to disentangle 'political corruption' from other types of 'particularism' with which it is often lumped, thus blurring the real contours of the phenomenon, so as to suggest ways in which it could be reined in by using the tools of electoral democracy itself.
An extensive literature has explored the main structural, historical, and cultural factors purporting to explain Italian exceptionalism, but the persistence of Italian corruption despite the country's undeniable economic and democratic progress since unification and then after WWII still proves an interesting puzzle (Uslaner \& Rothstein, 2016). The more recent literature has rather highlighted the importance of contemporaneous institutional developments.

This literature broadly subscribes to a rational institutionalist approach according to which politicians aim to maximize officeholding, votes, and policy outcomes, pretty much in that order (Budge \& Laver, 1986). Prioritization of officeholding and long-term incumbency is the hallmark of 'personalism' (Cain, Ferejohn, \& Fiorina, 1987). Later a set of indicators and some fairly sophisticated models to explain the degree of particularism 
in any given political system were developed (Carey \& Shugart, 1995; Seddon-Wallack, Gaviria, Panizza, \& Stein, 2003), but did not succeed in sufficiently distinguishing between different forms of particularism. It is our contention that not all forms of particularism are equally prejudicial to democracy, and that some may indeed be a necessary step toward defeating corruption.

In this article, we concentrate on the Italian case, an OECD country that, despite having reached remarkable levels of development and wealth, still appears to be beset by widespread corruption. We chose the Italian case also for methodological reasons, as Italy went through three major electoral reforms in a relatively short period of time (1993-2018). We believe that the Italian case allows us to analyze whether the electoral system may expand or shrink the room for particularism, and whether such particularism is pursued through programmatic appeals, pork-barrel politics, and constituency service, or through corrupt exchanges (concession of permits, procurement contracts and other types of preferential treatments in exchange for money).

The devastating effect that the unveiling of widespread corruption by the 'Clean Hands' investigations had on the postwar Italian party system (Della Porta, 1992; Della Porta \& Vannucci, 1995, 1999) would naturally lead to expect that the electoral reforms would have as their main goal the removal of incentives for corrupt deals. The reforms that followed, however, were aimed at other objectives (broadly considered ancillary to the fight against corruption but not directly related to it) such as securing alternation in government, simplifying the party system, and making government formation more closely dependent upon electoral results. In this article we investigate the indirect impact that those electoral reforms had on corruption control.

Although the literature is far from having reached a consensus, we start from the assumption that single member plurality (SMP) systems are more conducive to constituency service and pork-barrel politics than closedlist proportional representation (CLPR) and that open-list proportional representation (OLPR) is more conducive to rent-seeking and corruption. These are very different types of particularism that may lead to suboptimal allocation of resources, but that differ in terms of their impact on the legitimacy of the system and the citizens' assessment of democracy. We observe that the period in which a high proportion of Members of Parliament (MPs) were elected in single member districts within a mixedmember (MM) system coincided with the period during which corruption control was taken more seriously and the perception of corruption abated. However, the return to CLPR systems (once again, dictated by other goals than that of fighting corruption) dampened that effect and ushered in a reversal of the trend in the perception of corruption control.

We propose a very preliminary 'test' of this propositions by comparing Italy to four other political systems characterized by electoral systems that lie on a sort of particularism gradient from SMP (UK) to MM proportional (Germany) to majority (France) to proportional representation (PR)-albeit with significant checks tempering its proportionality-(Spain) system. What emerges from this comparison is still a sort of Italian exceptionalism because levels of perceived corruption are constantly higher and, contrary to what happens in the other political systems, left-wing governments are perceived to be more serious about corruption control than right-wing governments.

The article develops as follows. In the next section, we take stock of the literature on personalism and illustrate the incentives for the supply of particularistic politics. Section 3 elaborates on the various forms of particularism and, drawing from the existing literature, establishes criteria according to which different electoral systems can be expected to create larger or narrower margins for the different types of particularism. Section 4 presents the background on our case study, while Section 5 discusses various measurement options of the dependent and independent variables and offers a (preliminary and suggestive) test of our argument by means of proxy indicators for clientelism, patronage, and corruption. Section 6 concludes the article.

\section{The Determinants of Particularism}

The literature on particularism has its roots in the analysis of "the personal vote" (Cain et al., 1987). The personal vote is the share of the total vote which is obtained thanks to the personal appeal of the candidate, because of his/her past legislative record and/or programmatic commitments. By cultivating a personal vote, legislators aim at being elected and re-elected, thus increasing the chances of their continuing incumbency. The contrast that this concept seeks to establish is between the motivations that voters have for electing candidates based on their personal appeal (personal reputation) and those based on party appeals (party reputation).

There is no implication, in Cain's et al. (1987) thesis, that the party vote should be more objective and rational than the personal vote. In both cases, the motivations of the vote can be entirely objective and rational, whether reputational or programmatic. The personal vote can be operationalized and measured by such indicators as the politicians' personal roll-call vote record on specific policy options, by the time and effort they devote to 'constituency service,' and by how much public money they manage to bring to their communities. The original intuition behind the notion of personal vote gave rise to the systematic analysis of the institutional conditions that stimulate seeking the personal vote through what was labelled "particularism" (Carey \& Shugart, 1995; Seddon-Wallack et al., 2003). Several aspects of the electoral systems contributed to the supply of particularism, jointly suggesting that SMP, OLPR, and CLPR systems ranked at decreasing levels of particularism (cf. Cheibub \& Nalepa, 2020, pp. 4-6). 
Candidates running in SMP systems would need to pitch their promises and programs to local constituents, regardless of whether they happened to run in safe or contested districts. Under such a system, a broad appeal can be crafted by offering sectional benefits, i.e., benefits that accrue to the prevailing local interests regardless of whether other districts might be more needy or deserving. This electoral system, then, induces MPs to contravene the democratic expectation that legislative output should cater to the broad interests of the entire society, and as such is decried as particularistic.

PR systems in general should exert the opposite effect. Because the number of seats each party garners is determined 'by and large' by the electoral result across the entire national territory, the expectation is that crosssectional special interests will tend to be favored wherever they happen to be located and legislative output will indeed be universalistic. At the level of electoral district, however, the incentives for single candidates change depending on whether the system is closed- or open-list. In CLPR, candidates will want to run on the party platform since the more votes the party gets, the more candidates will be elected starting from those placed higher up on the list. In OLPR, candidates will have an interest in differentiating their electoral appeal as preference votes may secure election for popular candidates placed lower down on the list. In OLPR the incentives to cast a distinctive profile, to cater to locally prevalent categorical interests, or to get the vote by distributing selective benefits to clienteles are strong, so that universalistic public goods will be forsaken in favor of localized public goods, at best, or of private benefits to few, at worst (a more detailed discussion of this literature is presented in Section 3).

The literature that emanated from these seminal works focused on the incentives that electoral systems create for legislators to seek reelection through particularistic appeals, thus concentrates on the supply of particularism. Legislators must find the resources to pitch their personalistic pledges (Gingerich, 2009). As these will probably not come entirely from the party's coffers, because to some extent particularistic politics set individual candidates against party leaders, the quest for the personal vote may induce candidates and particularly incumbents to look for extra resources by asking for campaign contributions in exchange for public contracts ('kickbacks'), favorable legislation ('grease') or by infiltrating the public administration with trusted supporters and, through these, providing jobs and other selective benefits to voters (patronage). If state funds are directly 'skimmed' and end up 'lining individual candidates' pockets,' this is corruption at its ugliest. In this perspective, higher levels of particularism are associated with higher levels of (potential) corruption. This general conclusion, however, must be supplemented with a more fine-grained analysis of which type of particularistic exchanges each system promotes.

Voters are assumed to limit themselves to choosing between different types of particularistic bids, be they programmatic, selective at the level of constituency or sectional group (constituency service/pork-barrel politics), or selective at the level of individual voters (clientelism). They are generally assumed to prefer the provision of public goods according to universalistic criteria, but difficulties in monitoring the behavior of legislators and mounting collective actions in order to dislodge corrupt politicians make them rather passive receivers of the legislators' bids. The emphasis of the literature on particularism, therefore, relies heavily on an analysis of the 'supply side.'

The literature on corruption, on the other hand, tends to focus on the 'demand side,' to the extent that it highlights the monitoring and sanctioning activity of the voters. The starting point is the same-how different electoral systems create incentives for particularistic or corrupt exchanges-but the emphasis is then shifted from the incentives and opportunities for legislators to offer this or that type of particularistic appeal to the voters' (and competing candidates') interest and capacity to expose and sanction corrupt bids. In this literature, too, voters are assumed to prefer the provision of public goods according to universalistic criteria, but they are additionally assumed to actively sanction corrupt bids through their voting choices. In this they are helped by competing candidates interested in dislodging incumbent legislators by exposing their corrupt behavior.

For several reasons, we find this approach insufficient. Persson, Rothstein, and Teorell (2013) argue that, in thoroughly corrupt systems, efforts to fight corruption must be based on a collective action model that emphasizes the incentives that 'legislators' have in refraining from corrupt dealings rather than on a principalagent model that relies on the willingness of 'voters and competitors' to monitor and sanction corrupt behaviors. Without ascribing Italy to the universe of thoroughly corrupt systems, we still think that even in Italy individually rational voters and competitors will be willing to settle for suboptimal but nevertheless selectively rewarding incentives and will adjust their behavior to the mainstream, respectively. In other words, we believe that corruption ultimately can be curbed only through a second-order commitment on the part of legislators who collectively decide to change the systemic incentives in order to discourage corrupt particularistic exchanges for all.

We therefore shift the emphasis back on the legislators who are objectively better placed to overcome collective action problems and carry out such reforms, and we concentrate on Italy's electoral systems as incentivizing different types of particularistic exchanges.

\section{Electoral Systems and Incentives for Different Types of Particularistic Exchanges}

The universe of electoral systems is conventionally divided into PR, SMP, and MM systems (Farrell, 2011), but they are often regrouped by the literature according to corruption-relevant features, in particular the relative 
bargaining power that they lend party leaders vis-à-vis individual candidates (the supply side) and the incentives that they create for voters and competing candidates to monitor and sanction corrupt behaviors (the demand side). Scholars disagree as to whether SMP or PR systems (and within this universe, OLPR or CLPR systems) grant more power to candidates or party leaders and whether they create stronger or weaker incentives for monitoring and sanctioning corruption on the part of voters and competing candidates. The conventional wisdom after Carey and Shugart (1995) and Seddon-Wallack et al. (2003) is that SMP, OLPR, and CLPR stand in a decreasing order of particularism. A debate immediately followed concentrating on the different types of particularistic bids that these systems incentivized and, therefore, on the consequences in terms of the production of public goods and the control of corruption.

Persson, Tabellini, and Trebbi (2003), focusing on the demand side, argue that SMP systems are more prone to corruption than PR systems because the latter are associated with larger electoral districts, more intense competition, and greater opportunities for monitoring and sanctioning but do not distinguish between the types of particularism incentivized. Golden and Chang (2001) and Pellegata and Memoli (2018) show that in PR systems larger electoral districts make monitoring more difficult, enfeeble accountability and ultimately favor corruption. Ceron and Mainenti (2018) argue that voters are more inclined to forgive corruption charges if they can select the candidates. As this influence may be exerted either through preference voting in OLPR systems or in MM systems, they produce further evidence to support the common claim that OLPR systems are more prone to corruption than CLPR.

District magnitude, a variable that had been found by Carey and Shugart (1995) to exert opposite effects in CLPR and OLPR systems, became the object of a heated debate that introduced other dimensions of electoral competition and prompted a reconsideration of the overall effects of electoral systems on both the supply and the demand of particularism. For example, André, Depauw, and Martin (2015) argued that the candidates' perceived 'vulnerability' is capable of offsetting the disincentive to pay attention to constituents generated by CLPR and of reinforcing the incentive generated by OLPR. They conclude, in line with Carey and Shugart (1995), that "district magnitude has a differential effect dependent on the ballot structure": It decreases constituency effort in CLPR systems and increases it in OLPR systems since in this system candidates are generally speaking more vulnerable (Carey \& Shugart, 1995, p. 486). With reference to Italy, Chang and Golden (2007) concurred.

The recent literature, however, questions the expectation that OLPR systems would be more prone to corrupt exchanges than CLPR systems. Kselman (2020) argues that OLPR systems are associated with higher efforts at producing public goods at the district level (what we would call constituency service) than CLPR:
In the current paper, public goods are produced at the level of multimember proportional representation (PR) districts rather than the entire electorate. The 'scope' of public goods thus occupies an intermediate position between highly particularistic 'porkbarrel' policies in single-member district systems, and universalistic policies, which benefit the entire electorate equally. (p. 114)

He thus confirms the stronger effect of OLPR systems on the supply of a kind of constituency-centered particularism that we too differentiate from corruption proper, but which can nonetheless activate corrupt exchanges in an effort to draw resources to the district.

Other recent studies contest the conventional ranking of CLPR and OLPR along a gradient of increasing likelihood to generate corrupt exchanges by introducing other variables such as party leadership countervailing strategies in the compilation of the closed lists (Cheibub $\& \operatorname{Sin}, 2020)$, their use of preferential voting as sort of primaries for subsequent election rounds (Folke \& Rikne, 2020), and their importing in the party platform the messages of the candidates that fared best in previous elections under OLPR systems (Carroll \& Nalepa, 2020). These counterstrategies can be subsumed under the observation that party leaders learn from past elections and act strategically to counter personalistic tendencies (Mershon, 2020).

Other studies focus on both supply and demand sides. Kuniková and Rose-Ackerman (2005) discuss both aspects and argue that the relative autonomy of candidates vis-à-vis party leaders shifts the locus of corruption towards the former in SMP systems (and conversely shifts it to party leaders in PR systems), even though the greater ease with which the behavior of individual candidates can be monitored in SMP systems may moderate the effect. Interestingly, they distinguish between "corruption that personally enriches politicians" and "the use of campaign funds by politicians to purchase votes on an individual basis" (Kuniková \& Rose-Ackerman, 2005, p. 576). They discuss how accepting kickbacks from a company that promises to build a factory in the constituency should be considered, and observe that it will depend on "the distortions introduced by corruption in pork-barrel projects" (Kuniková \& Rose-Ackerman, 2005), but also underscore that the same features that encourage narrow geographic targeting also contain features that tend to dampen corrupt rent-seeking behavior by politicians. We agree that the word 'corruption' should be used to denote only individual rent-seeking and furthermore strongly agree that redirecting corruption from pure rent-seeking to pork-barrel politics or constituency service may be the first step on the path towards emancipation from corruption.

This brief reference to the literature that studies the effect of electoral rules on corruption shows how numerous the institutional variables and how complex their impact on corruption can be, and that the same 
variable (e.g., district magnitude, candidate vulnerability) can have opposite effects in different electoral systems. Together, these studies strengthen our resolve to focus on the supply-side of particularism and confirm our initial expectation that OLPR systems tend to make parties captive to particularistic drives and therefore precede both CLPR and SMP in the gradient of increasingly corrupt particularistic exchanges. The ranking based on a simple measurement of particularism (SMP > OLPR > CLPR) gets reversed when we focus on the kind of exchanges that get incentivized by these systems: In our case, properly corrupt exchanges (OLPR > CLPR > SMP).

\section{Particularism in Italy during the First and Second Republic}

In this article we concentrate on Italy and focus the analysis on the supply side of corruption. We are aware that incentives for corruption may depend on aspects of the electoral-institutional system that were designed with different objectives in mind. In Italy, concern over corruption, mainly attributed to the illegal extraction of public resources by political parties, competing party factions, and individual candidates, was second in importance only to the more general concern for the instability of governments and the lack of accountability of the political system (Mershon, 2002).

\subsection{The First Republic}

The First Republic (1946-1994) is the period investigated in particular by Miriam Golden in her many studies, alone and with colleagues. Golden and her colleagues constructed and experimented with a number of measures of corruption, using both the number of parliamentary authorizations for court cases to be brought against MPs indicted for wrongdoing (Golden \& Chang, 2001) and the difference between the earmarked funds for public works and the cumulated value of the works effectively brought to completion (Golden \& Picci, 2005, 2008) to pin down the dependent variable. Her findings mainly concern the pivotal party of Christian Democracy (DC), which was in power without interruption between 1948 and 1994 but can be extended to the other governmental parties as well, particularly from the mid-1970s onward. First, political corruption was significantly associated with intra-party competition and, in the early postwar period, substantially unaffected by inter-party competition (Golden \& Chang, 2001, pp. 592, 594). Second, the 1974 law on public financing of parties, which "directed funds to party organizations... and left individual candidates on their own to raise the necessary campaign funds" (Golden \& Chang, 2001, p. 596), paradoxically created additional incentives to engage in corrupt exchanges. Third, henceforth corruption "contaminated" the smaller coalition partners as well, since they had to be taken into consideration in the division of kickbacks and spoils in order to keep the lid on the actual system of campaign financing (Golden \& Chang, 2001, p. 605). Fourth, interparty competition had a limited impact on corruption until the Italian Communist Party (PCI) won an impressive electoral result at the 1976 national elections (Golden \& Chang, 2001, p. 611) and shook the existing system, but also created the premises for a "consociational" division of the spoils.

The rather somber conclusion to which Golden and Chang arrive is that in 1994 the Italian political system was on a path of growing corruption, since politicians not prepared to use such tactics were crowded out by the competition (Golden \& Chang, 2001, p. 613). A similar rational-institutionalist approach characterizes the analysis of political patronage in Italy-the distribution of positions in the public administration to friends and followers-and leads to the conclusion that redundant and contradictory legislation was purposely made by Italian politicians so as to be able to then act as "facilitators" with the public administration on behalf of their voters (Di Mascio, 2012; Golden, 2003; Golden \& Picci, 2008). Yet, as emerges from Golden and Picci (2015), despite such intense vying for visibility and personalization on the part of candidates, there appeared to be no incumbency premium in pursuing the personal vote through corrupt means. This result is somewhat counterintuitive, and points to party leaderships that, until 1992, managed to control the selection of candidates despite the effort of candidates to curry the personal vote, but it is broadly in line with the evidence discussed by Carroll and Nalepa (2020), Cheibub and Sin (2020), and Folke and Rikne (2020).

Impressive as they are, Golden's findings suffer from two shortcomings. First, her analysis stops at 1994, after which almost everything changed in Italy, from the individual parties to the electoral system, from the rules on party financing to the ease with which MPs could be investigated and indicted. Second, she does not differentiate among different types of particularism but rather considers all particularistic exchanges as 'corrupt.' We, on the contrary, believe that different types of particularism should be assessed differently. In an effort to find ways to fight corruption, it makes a lot of difference whether the personal vote is cultivated by articulating a distinctive programmatic platform, funneling central moneys to the local constituency as a whole through public projects of general utility, or favoring certain local special interests over others. It also makes a lot of difference whether particularism takes the form of fairly harmless constituency service, as in the UK (also see Piattoni, 2007, on different types of Southern Italian clientelism), entrenched pork-barrel politics, or flagrant defiance of laws and regulations.

The present article seeks to make a contribution to this literature by extending the above argumentative line to the post-1994 period, during which Italy experimented with three new electoral systems, and by trying to distinguish between different types of particular- 
ism induced by electoral reforms ostensibly aiming at other goals.

\subsection{The Second Republic}

Although suspicions that the system had become thoroughly corrupt circulated at least since the end of the 1980 s, the pervasiveness of corruption that was unveiled was astounding. Not even relatively new parties (such as the Lega Nord) or parties which had made a battle cry out of the "moral question" (the PCI) were found to be immune from corruption. The end of the 1980s marked a veritable historical watershed, as the dénouement of the Cold War brought to an end not only the division of the world in two blocs but also the flow of party financing from the US (to the DC and the other bourgeois and liberal parties) and the USSR (mostly to the $\mathrm{PCl}$, and originally also the Italian Socialist Party [PSI]). Meanwhile, the electorate had become more fluid and willing to vote for new parties. New issues-regional autonomy, the adoption of the euro, and a nagging sense of slipping behind the rest of 'Europe'-mobilized voters in new ways. This 'perfect storm' further weakened the postwar parties' grip on the electorate and put wind in the sails of a class of magistrates eager to clean up the rotten postwar system. Outraged citizens stopped voting for the traditional parties and turned their support to new ones such as the Lega Nord (an alliance of political movements located mainly in the north of the country seeking to detach themselves from an allegedly vexatious political center) and the Forza Italia party of Silvio Berlusconi. In the 1992 elections the historical postwar parties were weakened and in 1994 they were effectively wiped out.

An impressive series of reforms, some spearheaded by the political elite, other bargained between elites and masses (Renwick, 2011), and some even prompted by judicial activism (Massetti \& Farinelli, 2019), have been implemented particularly since the early 1990s. The early postwar reforms had aimed at stabilizing the party system and allowing ample expression of the many conflicting orientations that characterized an extremely polarized electorate. In the circumstances, PR had been the obvious choice but its open-list variant activated clientelistic relations which in turn ignited corrupt exchanges. The need for an electoral system that would guarantee voters' choice while incentivizing a healthier form of particularism -in practice the adoption of a SMP system-was at the center of the 1987 referendum initiative spearheaded by the Radical Party (Baldini, 2011, p. 650). The referendum failed, but the need for a system that would minimize the space for corrupt exchanges remained: "PR had turned from being a cornerstone of the political system to the main target of the reformers' actions" (Baldini, 2011, p. 650). The 1991 referendum organized by DC reformist leader Mario Segni, which registered an impressive participation rate and an unprecedented consensus $(95,6 \%)$, succeeded in eliminating multiple preferential voting, universally identified as the in- stitutional device for corrupt exchanges. The other objective (reforming the OLPR system into a majority, tworound SMD system similar to the French one), however, failed. Since the late 1980s, most observers concurred that governmental instability and lack of accountability were the gravest evils of the Italian political system, and that corruption was a side-product of that system.

The overarching concern now was to lend executives greater durability, making government formation more immediately dependent on electoral results, and securing alternation in government. An intermediate objective, seen as instrumental for achieving both main goals, was to reduce the number of parties and/or incentivize the formation of pre-electoral "political poles" that would compete as if they were single parties. These goals suggested the adoption of a MM (but mainly SMP) electoral system that would hopefully ease the transition from the fragmented and fractious postwar party system to a simpler and more orderly one. For a long time, the objective was to arrive at a SMD majority system (Bartolini, D’Alimonte, \& Chiaramonte, 2002). The pressures that had built up since the late 1980 s eventually led to a reform of the "mass-elite interaction" type which, in mature economies, should lead to greater personalization of the vote (Renwick, 2011, p. 463). The Mattarella laws (n. 276 and 277, 4.8.1994) succeeded in changing the electoral system precisely in this direction. The ensuing system was a mixed member system that allocated $75 \%$ of parliamentary seats through a SMD system and $25 \%$ through a closed-list PR system.

As Baldini (2011, p. 654) affirms, "The 1993 reform was the result of different, and sometimes conflicting, pressures that weak and increasingly delegitimized parties could not ignore." There were two aims to this reform: On the one hand, the incentives for the cultivation of a corrupt personal vote were to be minimized and those for a healthier form of constituency service maximized; on the other, the system was meant to induce parties to announce their programmatic alliances before elections, in view of building stable governmental coalitions that could last the entire legislature. It had been recognized that one of the problems of the postwar Italian political system had been the extreme fickleness of governmental coalitions, which often collapsed simply because some intra-party faction or powerful member had become dissatisfied with the current allocation of governmental and patronage positions. Fewer, stronger parties organizing themselves into two opposed political blocs would yield more stable governments and more coherent fiscal and monetary policies. Unfortunately, the reform achieved the former goal but failed to achieve the latter, which in turn prompted further reforms aimed at simplifying the party system and making competing alliances more credible and durable (the details are in Regalia, 2018, pp. 85-91).

On the basis of the classifications of electoral systems operated by Carey and Shugart (1995) and the ordinal measures of the same proposed by Seddon-Wallack 
et al. (2003), it is theoretically possible to calculate the room for particularism offered by each electoral system. An attempt in this direction was made by Piattoni and Mainenti (2007) after the Mattarella electoral reform, and further conjectures were formulated by Piattoni (2018) with regard to the two following reforms in 2005 and 2017. However, solid quantitative tests have not been carried out for want of reliable measurements of the dependent variable and for the difficulty of considering all the institutional and procedural details that affect the type of inter- and intra-party competition that these electoral reforms have triggered. So, while it is possible to hypothesize that the Mattarella law of 1993 increased the incentives for constituency service and reduced those for clientelist or corrupt forms of particularism, this cannot easily be proven. While the allocation of most parliamentary seats by SMP (and the concomitant liquidation of a large part of the old political class) opened up many seats to candidates from new parties and to distinguished personalities previously uninvolved in politics, in subsequent elections parties found ways of 'reproportionalizing' some of these seats, thus claiming control over their allocation (D'Alimonte \& Chiaramonte, 2010). This electoral law yielded a bipolar political system, one of the objectives of the reform, but also extremely fragmented center-right and center-left coalitions, which remained hostage to the blackmail of even the smallest of their constituent parties (Regalia, 2018).

Given the continued instability of governmental coalitions even within a bipolar system, in 2005 the electoral law changed once again, and the system was substantially reproportionalized. The Calderoli law (n. 270, 21.12.2005) replaced the Mattarella mixed electoral system with a CLPR system and introduced a majority bonus for the party or coalition that obtained the largest number of votes in the lower or upper chamber. The new system was essentially proportional, but introduced some correctives-long closed lists in order to help keep party discipline, various types of thresholds for seat allocation for parties running together or running separately, thus favoring pre-electoral coalitions, the possibility for popular party leaders to run in several districts and later choose which seat to represent, thus gaining the relinquished seat(s) for the following candidate on their listaimed at helping the formation and duration of governments and of limiting the personal vote and favoring party discipline. The Constitutional Court subsequently declared the Calderoli law unconstitutional, citing the excessive length of the lists and size of the majority bonus, which prompted a further reform of the electoral law.

Three elections were held under the Calderoli system $(2006,2008$, and 2013) which however yielded different results as a consequence of the changing strategies of party leaders. D'Alimonte and Chiaramonte (2010) specifically discuss the different strategies pursued during the 2006 and 2008 elections. During the first, the main left and right coalition parties tried to mop up all possible votes from all smaller parties which could be attracted to their side and thus put together very fragmented and fractious large coalitions which quickly dissolved under the pressure of excessive intra-coalitional requests. During the second election, both leading parties managed to form much tighter coalitions, thus decreasing the blackmail potential of the smaller parties, which for the most part could hope to win only a handful of seats. Inter- and intra-party competition in the two election rounds, therefore, differed not because the electoral system had changed, but because the party strategies had. These differences are hard to model, and it would consequently be difficult to formulate hypotheses on the incentives that this electoral system produced in terms of particularistic exchanges. For this reason, in what follows, we limit ourselves to testing the general trend of corruption control under the two electoral systems, Mattarella and Calderoli, between 1996 and 2016. The third reform, known as the Rosato law, is too recent and has so far been used only in the 2018 elections (law n. 165, 3.11.2017).

\section{Evidence}

Measuring corruption is hard, and the difficulties in capturing the phenomenon with quantitative data are wellknown to the scholarly literature, as discussed above. The problems inherent in the measurement of any criminal/sanctionable activity, especially those committed by social and political elites, are compounded by debates on the nature and scope of the concept, as well as by cultural differences across countries and time periods. Various strategies of operationalization have been followed by scholars in the field, with varying degrees of success. Most large- $\mathrm{N}$ studies covering significant time spans in a multi-country framework have adopted a reputational approach, enquiring after the perception of corruption in a given country at a given time. The public whose views form the basis of the indicator may vary, from political science experts to ordinary citizens to market participants, domestic or foreign. Despite the significant drawbacks of this strategy, the chief among which being cultural bias and path-dependency, it remains the soundest and most parsimonious for comparative purposes, and as such has been adopted herein.

In order to shed light on the Italian case, we have made recourse to three composite measurements of corruption, produced by three entities: the World Bank's Worldwide Governance Indicator Control of Corruption (WB; World Bank, 2018), Democracy Barometer's Absence of Corruption (DB; Merkel et al., 2018), and International IDEA's Global State of Democracy Absence of Corruption (ID; International IDEA, 2019). Each of these indexes, in turn, is an aggregate of various different sub-measurements, with distinctive provenances and nuances. Although the definitions vary somewhat, as do the scales ( -2.5 to 2.5 for WB, 0 to 100 for $D B$, 0 to 1 for ID), we consider them as broadly comparable measurements of the perceived level of corruption, with 
a higher score corresponding in all cases to a more 'virtuous' situation. All three datasets' historical series begin in the 1990s. The consequent limitations of the data, in order to ensure comparability, oblige us to curtail the scope of our analysis to the two decades 1996-2016: Hence, we are able to measure the (perceived) level of corruption in Italy during the 13th through (part of) the 17th legislature, the first two of which (1996-2006) were selected with the mainly-majoritarian Mattarella electoral law, and the rest with the mainly-PR Calderoli law.

When we consider the data from these indicators, the first macro finding is a trend: The perception of how corrupt Italy is deteriorated significantly from the late 1990s to 2016, across indicators (Figures 1 and 2). As our explanatory variable is ordinal (the shift from an electoral system hypothesized to induce less pathological particularism to one believed to foster more), the appropriate statistical treatment is an analysis of variance, with dummy variables introduced to represent the different electoral systems; furthermore, as the choice is binary (Mattarella electoral law vs. Calderoli electoral law), the analysis simplifies to a one-tailed t-test of the difference in means between the value of the corruption indicator in 1996-2005 and in 2006-2016. The difference has the correct sign, and the test is statistically significant well below the 0.01 level for both the WB and DB indicators (see replication materials), hence consistently with our hypothesis about the incentives of the two electoral regimes.

Given the large number of plausible confounders, and the small $\mathrm{N}$ of the country-year observations for our indicators, the strategy pursued for checking the robustness of our results relied on the multi-country nature of all the data-collection projects from which our indicators were drawn. Specifically, this fact allowed us to place Italian corruption perception in context by comparing it with other European cases. Data for four representative Western European countries from these same databases are presented: Spain, France, Germany, and the UK are often employed comparatively, as they have somewhat similar population and GDP size, as well as being (at the time) fellow EU members, but their political cultures and institutions are distinctive. In particular, their electoral systems fall on various points of the 'continuum of particularism' described above (mainly PR systems for Spain and Germany, more majoritarian ones for France and the UK). Crucially, however, none of these democracies experimented with changes in their electoral laws in the period 1996-2016.

When one considers either the four-country average or the single paths, it is apparent that Italy is an outlier with regard both to the rate of decline in corruption control over the period and to the very low starting level. If the latter may be imputed to secular factors related to po-

World Bank Worldwide Governance Indicators: Control of Corruption

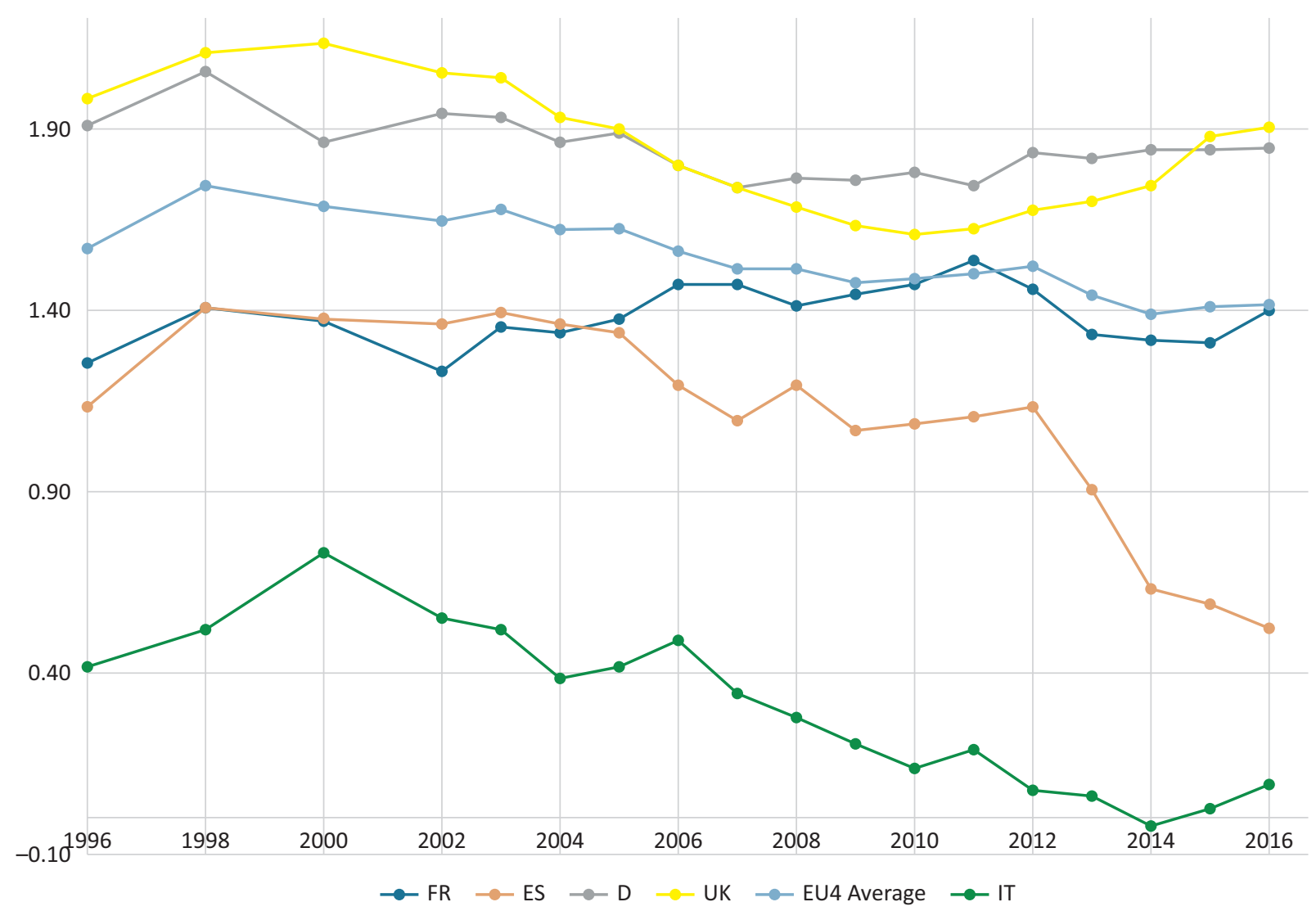

Figure 1. WB indicator. 
Democracy Barometer: Absence of corruption

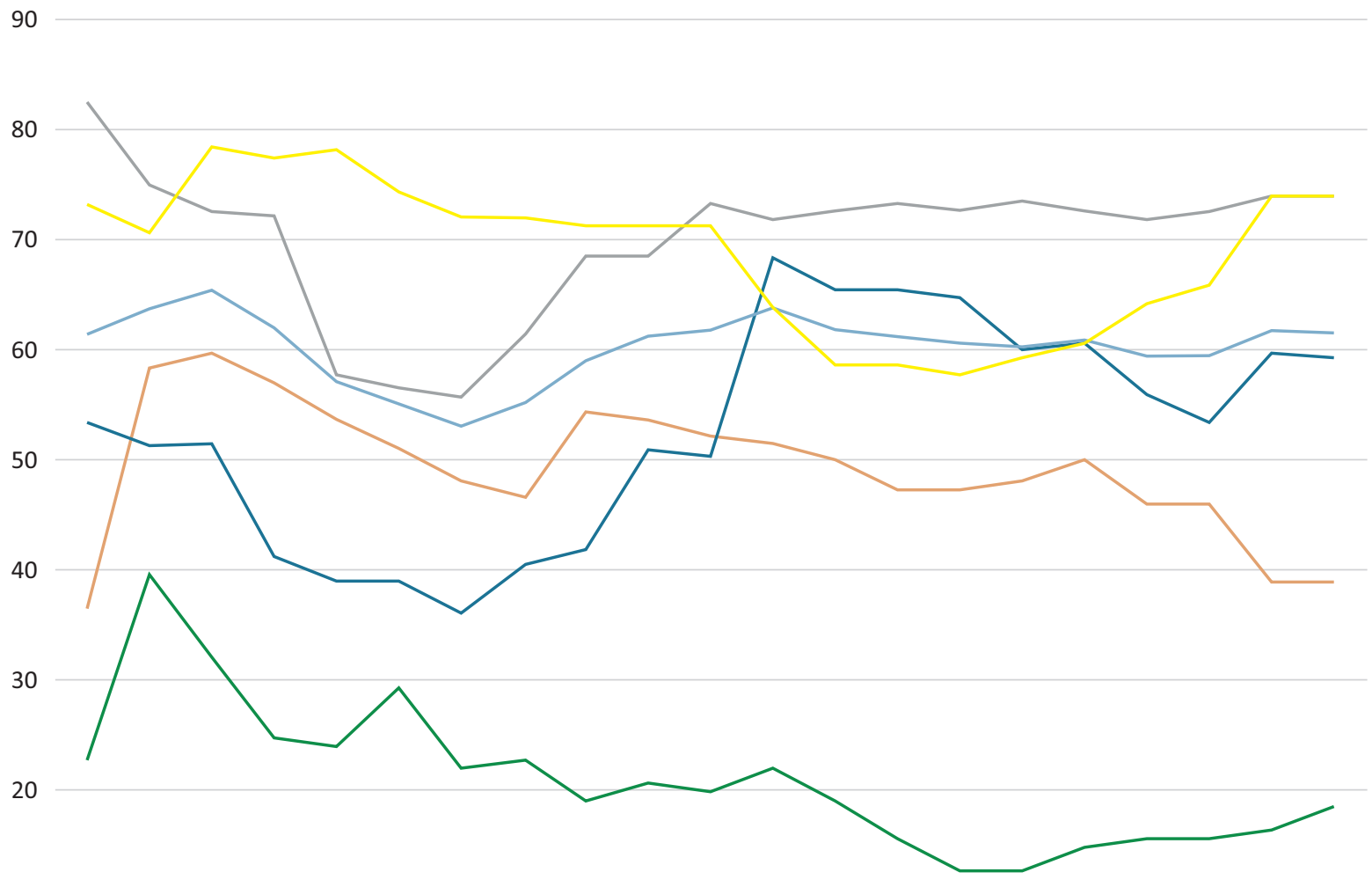

10

199619971998199920002001200220032004200520062007200820092010201120122013201420152016 $-\mathrm{FR}-\mathrm{ES}-\mathrm{D} \longrightarrow \mathrm{UK} \longrightarrow \mathrm{EU} 4$ Average $-\mathrm{IT}$

Figure 2. DB indicator.

litical culture and societal trust, the former remains puzzling. What can be concluded is that electoral systems do not dictate absolute levels of corruption perception across countries per se but changing electoral systems may set in motion certain reputational changes.

The third indicator we consider presents a somewhat different story. The variation over the period is much more nuanced (Figure 3), and the difference in means between the two periods falls within the margin of error. A potential explanation for this different finding is that the ID indicator is significantly weighted toward expert scholarly opinion rather than policymakers/market participants. The disaggregated distribution of sub-indicators (Figure 4) that make up the ID indicator is instructive: The first four-respectively labeled "Public sector corrupt exchanges," "Public sector theft," "Executive embezzlement and theft," "Executive bribery and corrupt exchanges," (Tufis, 2019, pp. 121-126)-are all stationary or oscillate around a mean: An indication, perhaps, of stable perceptions of governmental behavior, or the personal reputation of leading politicians alternating in power. It is interesting to note that Public Sector Theft, which could be taken as a proxy for patronage, remains constant during the period of observation, indicating Italy's long-term failure at building a bureaucracy "entrenched behind a statute of bureaucratic autonomy" (Shefter, 1994). On the contrary, the indica- tors of "political" corruption display more variation and appear to be more sensitive to changes in institutional factors. The only indicator with a secular negative trend is the fifth one ("Corruption"), which claims to capture the perceptions of the business community whose sentiment turned negative again once the hope for a thorough cleansing on the system were dashed in the early 2000s (see Tufis, 2019, p. 127). In any case, when compared with the other big-four West European democracies the fluctuations in the Italian indicator are more pronounced (and the baseline lower), and when considering only the fifth sub-indicator, no country displays the pattern of long-term decline witnessed in Italy (Figure 5).

Speaking of fluctuations and reputation, it is reasonable to consider whether there is any relationship between the country's reputation for corruption and the (partisan) identity of the occupants of executive office. In reputational studies of corruption, it makes sense to watch out for fixed effects, and the indicators adopted allow us to study these variations across countries. Table 1 summarizes the findings. The two decades 1996-2016 are divided into periods on the basis of the party holding a parliamentary majority. Hence, different administrations may be lumped together if their ideological orientation did not change (e.g., the Chirac and Sarkozy presidencies) or, vice versa, broken up (e.g., the Merkel chancellorship in 2005-2009, 2009-2013, and thereafter). 
IDEA Global State of Democracy: Absence of corruption

1.00

0.90

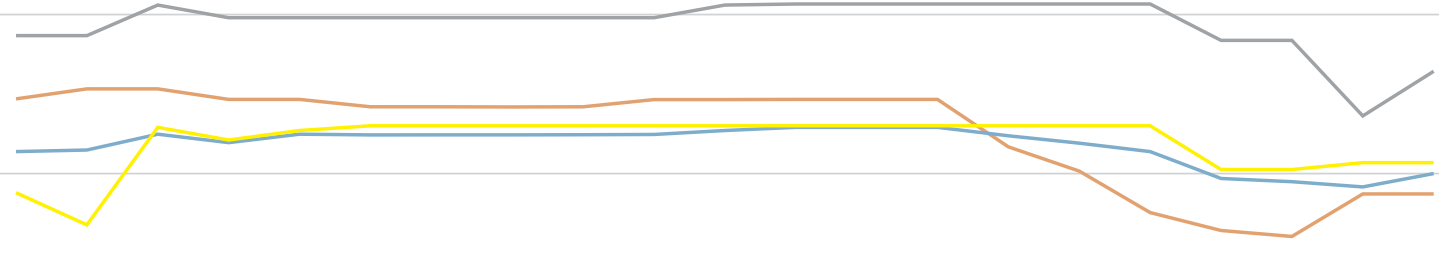

0.70
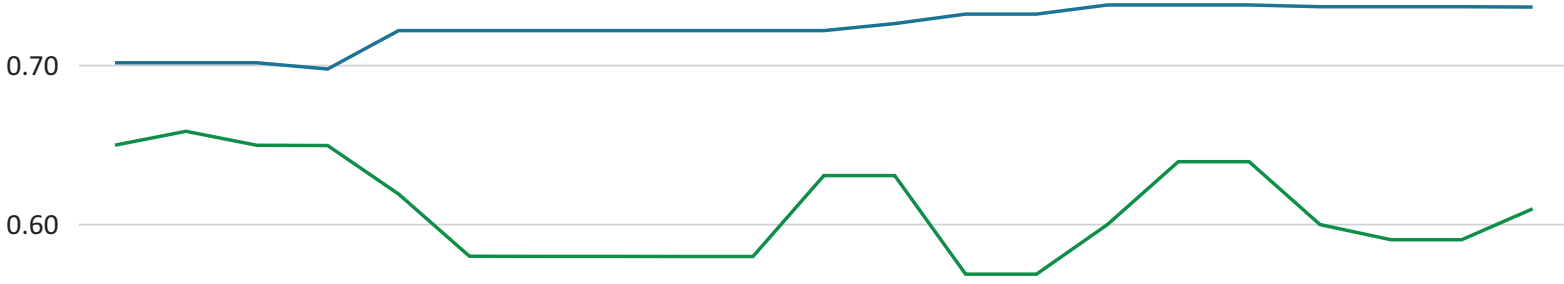

0.50

0.40

199619971998199920002001200220032004200520062007200820092010201120122013201420152016 - FR - ES - D UK UU4 Average — IT

Figure 3. ID indicator.

IDEA Global State of Democracy: disaggregated indicators for Absence of corruption (Italy)

1.00

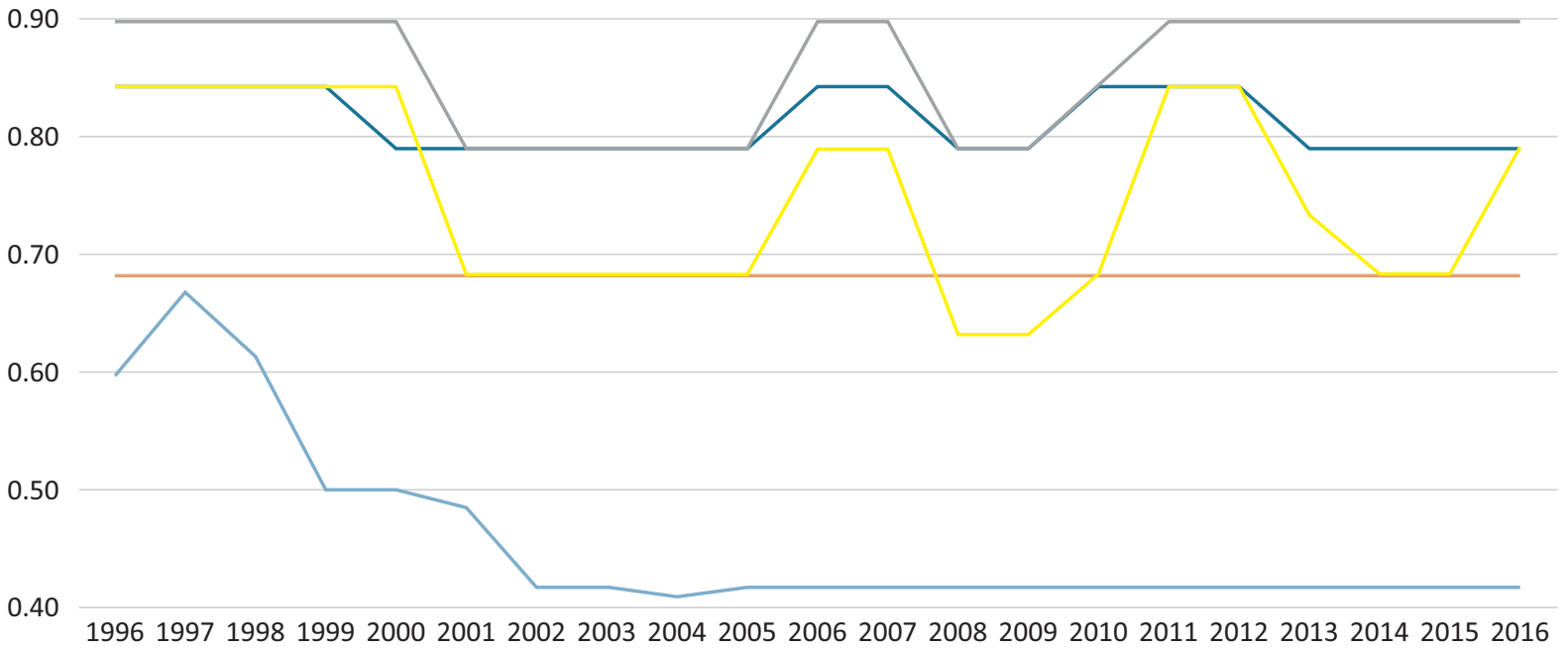

$$
\text { - v_41_01 - v_41_02-v_41_03-v_41_04-v_41_05 }
$$

Figure 4. ID sub-indicators. 
IDEA Global State of Democracy: disaggregated indicator for corruption

1.00

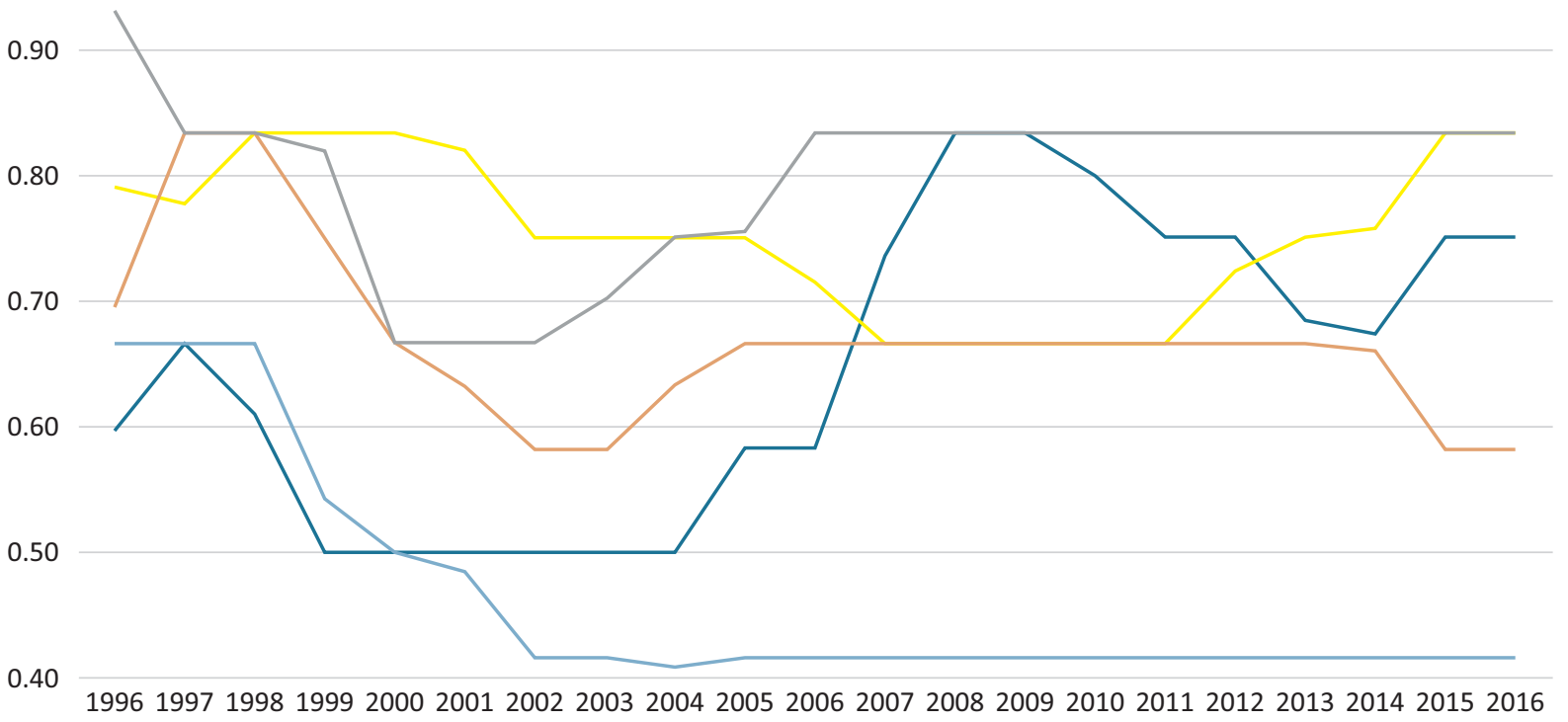

- FR v_41_05 ES v_41_05-D v_41_05 UK v_41_05 - IT v_41_05

Figure 5. ID 5th sub-indicator (“Corruption”), by country.

Table 1. Governments by parliamentary majority (1996-2016) in selected European countries.

\begin{tabular}{|c|c|c|c|}
\hline Government (by party parliamentary majority) & Length (years) & Ideological slant & $\Delta W B$ \\
\hline UK-Major & +1 & Right & 0.065 \\
\hline UK-Blair, Brown & 13 & Left & -0.445 \\
\hline UK-Cameron/LD & 5 & COAL & 0.28 \\
\hline UK-Cameron & $1^{+}$ & Right & 0.02 \\
\hline Germany-Kohl & +2 & Right & 0.14 \\
\hline Germany-Schroeder & 7 & Left & -0.16 \\
\hline Germany-Merkel/SPD & 4 & COAL & -0.13 \\
\hline Germany-Merkel & 4 & Right & 0.05 \\
\hline Germany-Merkel/SPD ${ }^{2}$ & $3^{+}$ & COAL & 0.03 \\
\hline E-Aznar & 8 & Right & 0.23 \\
\hline E-Zapatero & 7 & Left & -0.26 \\
\hline E-Rajoy & $5^{+}$ & Right & -0.58 \\
\hline France-Chirac & +1 & Right & 0.07 \\
\hline France-Chirac/PS & 5 & COAL & -0.09 \\
\hline France-Chirac ${ }^{2}$, Sarkozy & 10 & Right & 0.23 \\
\hline France-Hollande & $4^{+}$ & Left & -0.06 \\
\hline Italy_Prodi, D’Alema, Amato & 5 & Left & 0.23 \\
\hline Italy-Berlusconi & 5 & Right & -0.16 \\
\hline Italy-Prodi ${ }^{2}$ & 2 & Left & -0.21 \\
\hline Italy-Berlusconi ${ }^{2}$ & 3 & Right & -0.09 \\
\hline I-Monti & 2 & COAL & -0.13 \\
\hline I-Letta, Renzi & $3^{+}$ & Left & 0.03 \\
\hline
\end{tabular}

Notes: ${ }^{+}$indicates that the executive continued before or after the span of the dataset. 'COAL' indicates a government whose ideological balance straddles the right-left divide, as traditionally instantiated in the specific country. $\triangle W B$ is change in WB corruption indicator between the first and last year of the executive. For 1997, 1999, and 2001 values (not present in the WB database) the average of the year immediately preceding and immediately following were used. 
The WB indicator is presented here (the others are displayed in the replication material).

One factor is immediately apparent: While many traditional explanations of corruption in Italy during the First Republic focused on the lack of any real alternation of political personnel in power, this cannot be the reason for Italy's continued struggles with corruption since the 1990 s, for there was greater alternation in government in Italy than in any other country in our sample.

A few other considerations are in order. The three indicators do not yield a unanimous position as to the relation between length of government and effects on corruption. While WB data indicates a strong negative correlation between length of government and performance on corruption control, DB data presents a comparable positive correlation, and ID data a weaker version of the same. The WB and DB indicators concur, however, in picking up an ideological difference in the effect on perceived corruption: In the four European countries considered, right-wing governments tend to leave office with their country perceived as less corrupt than when they took office, while the opposite is true of left-wing governments. Coalitions straddling the left-right divide are seen as intermediate by WB, as vastly better than either right or left by DB. In Italy, however, the result is precisely the opposite: Both WB and DB spot a significantly better performance for left-wing rather than rightwing governments.

While this finding may be driven by idiosyncratic facts, such as the international reputation of Silvio Berlusconi (Fabbrini, 2013), it is possible to hypothesize an indirect effect through the electoral system, at least inasmuch as left-wing governments were widely expected to prove internationally responsible (hence also in fighting corruption) but the change in the electoral system in 2005 made it much more difficult for them to retain power, by weakening the ties of responsibility between popular electoral choice and government composition.

\section{Conclusions}

In this article, following an institutionalist perspective, we have argued for an effect of a shift in electoral regimes on the overall supply of particularism, hence on corruption levels as a whole. Moreover, we have tried to highlight how different electoral systems incentivize different types of particularism and argued that some can be used as intermediate steps on a path towards corruption control. These achievements are, however, dependent on whether they activate other political dynamics which then prompt reversed reforms.

Our empirical evidence can be interpreted as a first, tentative step in the direction of corroborating our theoretical hypothesis, by showing how perceived corruption declined somewhat after the majoritarian reform of 1993 and soared again in Italy after the reproportionalization of 2005; corruption control indices show a similar picture, with an improvement between 1996 and 2006 and a subsequent decline thereafter. Our preliminary conclusion is that, although the 1993 reform had ignited a positive trend towards healthier types of particularistic exchanges that promised to wean Italy out of political corruption, its side-effects in terms of increased fragmentation of the party system and increased instability of governmental coalitions prompted "counter-reforms" aimed at addressing these problems but which however rekindled the more systemic aspects of corruption (statecentered patronage; Di Mascio, 2014). More specific indicators suggest that a more comprehensive defense of our thesis must be left to future research and will have to rely on alternative strategies of data collection on the dependent variable, moving past the perception paradigm. We also argued that different electoral systems incentivize different types of particularism.

Our conjecture-that a SMP system might transform systemic corruption, performed by both parties and individual legislators under the OLPR system of the First Republic, into a 'healthier' system in which at least the interests of local constituencies are addressed-was partially borne out by our empirical analysis. We understand that this would be but a modest improvement and would not amount to the eradication of particularism. We realistically think that all representative systems encourage a mix of particularistic and universalistic appeals that can however strike healthier or more pathological balances. Our recommendation would therefore be to revise once again the Italian electoral law in view of creating a stronger linkage between individual candidates and their electoral districts without however enfeebling party discipline too much. We understand that this would probably be the outcome of a long transition in which institutional provisions would induce corresponding cultural shifts.

Our evidence also highlighted two other interesting and counterintuitive facts. The first is how much of an outlier the Italian case is in comparative perspective, both in terms of trend and of baseline: such a result calls for renewed attention to the case in a spirit of methodological pluralism, as it may well be that both long-term political culture dynamics and shorter-term incentive variations are at play. The second surprising finding has to do with the partisan reputations for corruption in Italy, compared to other European countries. How such a finding extends to present conditions, following the revolution in the political system wrought by the rise of the Five-Star Movement and the re-branding of the League as a populist radical-right party, may provide an interesting puzzle for future research.

\section{Acknowledgments}

We would like to express our sincere gratitude for the rigorous comments of the two anonymous reviewers and the many suggestions of the editor of the thematic issue. 


\section{Conflict of Interests}

The authors declare no conflict of interests.

\section{Supplementary Material}

Supplementary material for this article is available online in the format provided by the author (unedited).

\section{References}

André, A., Depauw, S., \& Martin, S. (2015). Electoral systems and legislators' constituency effort: The mediating effect of electoral vulnerability. Comparative Political Studies, 48(4), 464-496.

Baldini, G. (2011). The different trajectories of Italian electoral reforms. West European Politics, 34(3), 634-663.

Bartolini, S., D'Alimonte, R., \& Chiaramonte, A. (2002). Maggioritario finalmente? La transizione elettorale 1994-2002 [Majority, at last? The electoral transition of 1994-2002]. Bologna: Il Mulino.

Budge, I., \& Laver, M. (1986). Office seeking and policy pursuit in coalition theory. Legislative Studies Quarterly, 11(4), 485-506.

Cain, B., Ferejohn, J., \& Fiorina, M. (1987). The personal vote: Constituency service and electoral independence. Cambridge, MA: Harvard University Press.

Carey, J. M., \& Shugart, M. S. (1995). Incentives to cultivate the personal vote: A rank ordering of electoral formulas. Electoral Studies, 14(4), 417-439.

Carroll, R., \& Nalepa, M. (2020). The personal vote and party cohesion: Modeling the effects of electoral rules on intraparty politics. Journal of Theoretical Politics, 32(1), 36-69.

Ceron, A., \& Mainenti, M. (2018). When rotten apples spoil the ballot: The conditional effect of corruption charges on parties' vote shares. International Political Science Review, 39(2), 242-255.

Chang, E., \& Golden, M. (2007). Electoral systems, district magnitude and corruption. British Journal of Political Science, 37(1), 117-137. https://doi.org/ $10.1017 / \mathrm{S} 0007123407000063$

Cheibub, J. A., \& Nalepa, M. (2020). Revisiting electoral personalism. Journal of Theoretical Politics, 32(1), 3-10.

Cheibub, J. A., \& Sin, G. (2020). Preference voting and intraparty competition in open-list PR systems. Journal of Theoretical Politics, 32(1), 70-95.

D'Alimonte, R., \& Chiaramonte, A. (2010). Proporzionale se vi pare: Le elezioni politiche del 2008. Bologna: II Mulino.

Della Porta, D. (1992). Lo scambio occulto: Casi di corruzione politica in Italia [Hidden exchanges: Cases of political corruption in Italy]. Bologna: II Mulino.

Della Porta, D., \& Vannucci, A. (1995). Corruzione politica e amministrazione pubblica: Risorse, meccanismi, attori [Political corruption and public administration: Resources, mechanisms, actors]. Bologna: II Mulino.
Della Porta, D., \& Vannucci, A. (1999). Un paese anormale. Come la classe politica ha perso l'occasione di Mani Pulite. Bari: Laterza.

Di Mascio, F. (2012). Party patronage in Italy: A matter for solitary leaders. In P. Kopecky, P. Mair, \& M. Spirova (Eds.), Party patronage and party government in European democracies (pp. 229-249). Oxford: Oxford University Press.

Di Mascio, F. (2014). Exploring the link between patronage and party institutionalization: A historicalinstitutional analysis of the Italian transition. Democratization, 21(4), 678-698.

Fabbrini, S. (2013). The rise and fall of Silvio Berlusconi: Personalization of politics and its limits. Comparative European Politics, 11(2), 153-171.

Farrell, D. (2011). Electoral systems: A comparative introduction (2nd ed.). London: Red Globe Press.

Folke, O., \& Rikne, J. (2020). Who wins preference votes? An analysis of party loyalty, ideology, and accountability to voters. Journal of Theoretical Politics, 32(1), 11-35.

Gingerich, D. (2009). Ballot structure, political corruption, and the performance of proportional representation. Journal of Theoretical Politics, 21(4), 509-541.

Golden, M. (2003). Electoral connections: The effects of the personal vote on political patronage, bureaucracy and legislation in postwar Italy. British Journal of Political Science, 33(2), 189-212.

Golden, M., \& Chang, E. (2001). Competitive corruption. Factional conflict and political malfeasance in postwar Italian Christian democracy. World Politics, 53(4), 588-622.

Golden, M., \& Picci, L. (2005). Proposal for a new measure of corruption, illustrated with Italian data. Economics \& Politics, 17(March), 37-75.

Golden, M., \& Picci, L. (2008). Pork-barrel politics in postwar Italy, 1953-94. American Journal of Political Science, 52(2), 268-289.

Golden, M., \& Picci, L. (2015). Incumbency effects under proportional representation: Leaders and backbenchers in the postwar Italian chamber of deputies. Legislative Studies Quarterly, 40(4), 509-538.

International IDEA. (2019). The global state of democracy indices. Retrieved from https://www.idea.int/datatools/tools/global-state-democracy-indices

Kselman, D. (2020). Public goods equilibria under closedand open-list proportional representation. Journal of Theoretical Politics, 21(4), 509-541.

Kuniková, J., \& Rose-Ackerman, S. (2005). Electoral rules and constitutional structures as constraints on corruption. British Journal of Political Science, 35(4), 573-606.

Massetti, E., \& Farinelli, A. (2019). From the Porcellum to the Rosatellum: 'Political elite-judicial interaction' in the Italian laboratory of electoral reforms. Contemporary Italian Politics, 11(2), 137-157.

Merkel, W., Bochsler, D., Bousbah, K., Bühlmann, M., Giebler, H., Hänni, M., . . W Wessels, B. (2018). Democ- 
racy Barometer: Codebook (version 6). Aarau: Zentrum für Demokratie.

Mershon, C. (2002). The cost of coalition. Stanford, CA: Stanford University Press.

Mershon, C. (2020). Challenging the preferential proportional representation. Journal of Theoretical Politics, 32(1), 168-182.

Pellegata, A., \& Memoli, V. (2018). Corruption and satisfaction with democracy: The conditional role of electoral disproportionality and ballot control. European Political Science Review, 10(3), 393-416.

Persson, A., Rothstein, B., \& Teorell, J. (2013). Why anticorruption reforms fail: Systemic corruption as a collective action problem. Governance, 26(3), 449-471.

Persson, T., Tabellini, G., \& Trebbi, F. (2003). Electoral rules and corruption. The Journal of the European Economic Association, 1(4), 958-989.

Piattoni, S. (2007). Clientelismo virtuoso: Una critica non convenzionale [Virtuous clientelism: An unconventional critique]. Bari: Laterza.

Piattoni, S. (2018). Ma la politica italiana può ancora definirsi clientelare? [But can Italian politics still be considered clientelistic?]. Quaderni di Sociologia, 2018(78), 61-75.

Piattoni, S., \& Mainenti, M. (2007). Trends in the evo- lution of particularistic politics in Italy: Hypotheses on clientelism and corruption on the basis of recent data. Paper presented at the ECPR General Conference, Pisa, Italy.

Regalia, M. (2018). Electoral reform as an engine of party system change. South European Society and Politics, 23(1), 81-96.

Renwick, A. (2011). Electoral reform in Europe since 1945. West European Politics, 43(3), 456-477.

Seddon-Wallack, J., Gaviria, A., Panizza, U., \& Stein, E. (2003). Particularism around the world. The World Bank Economic Review, 17(1) 133-143.

Shefter, M. (1994). Political parties and the state: The American historical experience. Princeton, NJ: Princeton University Press.

Tufis, C. D. (2019). The global state of democracy indices codebook: Version 3. Stockholm: International IDEA.

Uslaner, E., \& Rothstein, B. (2016). The historical roots of corruption: State-building, economic inequality and mass education. Comparative Politics, 48(2), 227-248.

World Bank. (2018). Worldwide governance indicators. Retrieved from http://info.worldbank.org/ governance/wgi

\section{About the Authors}

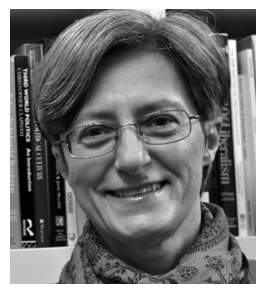

Simona Piattoni is Professor of Political Science at the University of Trento, Italy. She has been Chair of the Executive Committee of the European Consortium for Political Research (2012-2015) and President of the Società Italiana di Scienza Politica (2015-2018). She has written on clientelism, cohesion policy, multilevel governance, and European democracy. Among her books: Clientelism, Interests and Democratic Representation. The European Experience in Comparative and Historical Perspective (OUP, 2001) and The Theory of Multi-Level Governance. Conceptual, Empirical, and Normative Challenges (OUP, 2010).

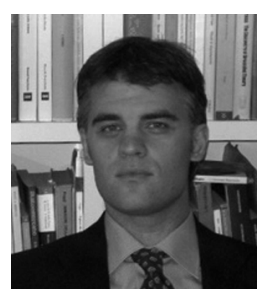

Matteo Fabio Nels Giglioli is an Adjunct Professor in the department of political and social sciences at the University of Bologna. His research interests lie at the intersection of political theory and comparative European politics. He has written on legitimacy, violence, populism, and wealth in politics. His latest book is I Labirinti della Sorveglianza Informatica: Cittadinanza e Impegno Politico nell'Era della Trasparenza Universale (II Mulino, 2020). 